\title{
New welfare state models based on the new member states' experience?
}

\author{
Miroslav Beblavý ${ }^{1}$ \\ Slovak Governance Institute \\ Faculty of Social and Economic Sciences, Comenius University
}

\section{Stream 4 Comparative methodology: worlds and varieties of welfare capitalism}

\begin{abstract}
The paper is concerned with the issue of how the postsocialist new member states of the European Union fit into the established methodologies of worlds and varieties of welfare capitalism. The paper argues that the postsocialist welfare state is different from the welfare states of the old member states and does not resemble any of the four existing models as present in Europe. The welfare states of the EU-10 countries are much smaller than those in the western half of the continent and generally demonstrate much stronger emphasis on redistribution to prevent poverty. The EU-10 are also highly internally differentiated as a group. We describe dimensions of welfare states in the new member states along three dimensions: size of the social protection expenditure, redistributive nature of the social transfers and relative redistribution effects based on the ratio between the first two variables. The size, and indirectly the shape, of the welfare state in the new member states is associated strongly with two factors: the size of the shock undergone by each economy during the transition and ethnic heterogeneity, particularly with regard to clearly defined and marginalised minorities. Based on these findings, we suggest provisional division of the Central and Eastern European welfare states into five groups. The provisional typology is based on the three dimensions of the welfare state identified above and position of each group along these dimensions is associated with potential determinants discussed above.
\end{abstract}

\section{Introduction}

The paper is concerned with the issue of how the postsocialist new member states of the European Union fit into the established methodologies of worlds and varieties of welfare capitalism. For much of the transition, this was more or less ignored because, with the rapid social, economic and political transition in the countries concerned, it was possible, indeed likely that they would, in the end converge to one of the established ideal types. However, with transition progressing, the position has become untenable and a variety of views has emerged, ranging from identification of the new member states as belonging to the liberal or residual regime to a creation of a new post-socialist type.

In this paper, we claim that:

- Methods used for fitting countries into the existing welfare regime typologies cannot be used directly in the new member states due to different history

- Alternative measure along three dimensions of welfare states - size of the social protection expenditure, redistributive nature of the social transfers and relative redistribution effects based on the ratio between the first two variables

\footnotetext{
${ }^{1}$ Beblavy@governance.sk
} 
- can be used which adequately captures internal differentiation of the EU-10 as a group

- the postsocialist welfare state is different from the welfare states of the old member states and does not resemble any of the four existing models as present in Europe

- the welfare states of the EU-10 countries are much smaller than those in the western half of the continent and generally demonstrate much stronger emphasis on redistribution to prevent poverty

- The size, and indirectly the shape, of the welfare state in the new member states is associated strongly with two factors: the size of the shock undergone by each economy during the transition and ethnic heterogeneity, particularly with regard to clearly defined and marginalised minorities.

- A new typology, based on these findings, can be developed for the EU-10, which divides them into five groups. However, the typology should be further refined to deal with classification of countries in the middle between the other four types.

\section{Welfare state typologies - a brief summary}

In reality, welfare states are hardly ever pure types and are usually hybrids (Arts and Gelissen (2002)). Nonetheless, Abrahamson (1999) notes proliferation of work on welfare state typologies, especially in the past two decades. Korpi (2000) suggests that the answer to their popularity lies in the fact that they serve as heuristic tools that allow researchers to organize and interpret information available in comparative studies.

In analyzing welfare states, a variety of typologies is possible. Mitchell identifies five main approaches to the comparison of welfare systems: comparison of policy, inputs, production, operations and outcomes. (Mitchell (1990)) Several typologies are possible using each of these approaches. Pierson (1995) identifies no less than 7 criteria according to which welfare states can be distinguished: range, reach, quality, tools, financing, type of benefit and redistribution. Again, each of them lends itself to one or more typologies.

Nonetheless, much of the debate about welfare state typologies over the last 18 years has revolved around the typology produced by Esping-Andersen (1990). This is despite the fact that his is neither the first (Abrahamson (1999)), nor universally accepted (Lewis (1992)). Indeed, subsequent work tends to use Esping-Andersen's work as the intellectual springboard regardless of whether it agrees or disagrees with him.

According to Esping-Andersen (1990), there are three models of welfare capitalism:

1. liberal welfare state (USA, UK, Canada, Australia, Ireland and New Zealand)

2. conservative welfare state (e.g. France, Germany, Austria, Belgium)

3. social-democratic welfare state (Sweden, Norway, Denmark, Finland)

The distinction is based on the dimensions of de-commodification, social stratification and public-private mix. They also reflect different political philosophies and traditions in the countries concerned, particularly the particular shape of the power structure during the welfare state creation: "The history of political class coalitions [is] the 
most decisive cause of welfare state variations...It is a historical fact that welfare state construction has depended on political coalition- building. The structure of class-coalitions is much more decisive than are the power resources of any single class." (Esping-Andersen 1990: 1, 30). For example, in continental welfare states, "these regimes institutionalized a middle-class loyalty to the preservation of both occupationally segregated social-insurance programs and, ultimately, to the political forces that brought them into being". (Esping- Andersen 1990: 31-32)

Of course, the whole Esping-Andersen typology is based on the assumption of path dependency. Otherwise the social and political developments a century ago would have little bearing on the current shape of the welfare state. Societal models, by their very nature, tend to be durable. Much research has been devoted to exploring why particular countries tend to adhere to different organizing paradigms even while they change many particular aspects of them in response to major internal and external shocks, but also to how they came to adopt these paradigms in the first place. (Titmuss (1974), Esping-Andersen (1990)) Most of the literature tends to see at least some role for path dependency effects (Pierson (2004)), where certain key decisions made at certain critical junctures structure and limit available choices for decades to come. (Though this should not be construed in an excessively rigid sense (see Crouch (2001).)

Empirically, organizing paradigms of welfare regimes applied in individual countries tend to be very sticky, which makes the issue of how the original paradigm was selected extremely important. At the same time, welfare states in industrialized countries of Western Europe and North America have undergone significant changes during 1980s and 1990s, frequently labelled as "welfare state retrenchment", (Pierson (1994)) even though it should be noted that the scholarly evaluation of the extent of these changes is that the rhetoric exceed actual change (ibid.). (Hacker (2004) presents a counterargument, but it is more in terms of lack of new policy initiatives than dismantling existing policies.) Castles' analysis (2004) confirms the hypothesis that the welfare state is not losing its position and that the welfare regimes are still keeping their specific profiles ('steady state welfare state') although there are some signs of convergence.

Let us now turn to critiques of Esping-Andersen. The critique of the mainstream typology comes in three basic shapes of increasing radicalism:

- critique pointing to specific deficiencies or arguing for new types. As Arts and Gelissen (2002) note, the most frequent criticisms concern identification by Esping-Andersen of the Mediterranean welfare states as immature conservative ones and the labelling of the Antipodean welfare states as belonging to the liberal regime type; Castles and Mitchell $(1992,1993)$ argue that liberal countries are highly diverse internally; Kwon (1997) tries to extend the typology to East Asia and ends up arguing for a new type for countries such as Korea and Japan.

While the Esping-Andersen typology has been subject to fierce critique (Abrahamson (1999) points to the excessive focus on social insurance, state and market on one hand and the neglect of personal social services and civil societal institutions on the other hand. Many scholars (e.g. Jenson (1997), Lewis (1992), Sainsbury (1999), Leitner (2003)) point to the missing gender dimension of the typology and have produced 
modifications or different typologies based on the inclusion of the gender aspect - see below for a detailed discussion, Kasza (2002) argues that it is unlikely that any country will be close to the same type across major social and economic policies due to diverse histories of actors, policies and policy-making in different welfare fields. Bambra (2005) supports this view by a specific analysis of health care policies)

However, the Esping-Andersen typology remains dominant in comparative discourse on the welfare states The success of the typology is based not only on its intuitive appeal to comparative researchers, but also on the fact that it ties together a particular shape of the welfare state with the political and social history behind its establishment. It will therefore also be a point of reference for us in this paper even as we argue that the typology cannot be used in the new member states precisely because of its rootedness in the evolution of welfare states at the end of the $19^{\text {th }}$ and the first half of the $20^{\text {th }}$ century. However, we will utilise the additional Mediterranean type which Esping-Andersen originally classified as immature conservative type, but later research has shown to be quite distinct in several respects. (Arts and Gelissen (2002))

\section{Welfare states in the new EU members}

Despite their common origin, nearly two decades of the transition, combined with some existing initial differences, have led to a high level of differentiation in the current shape of postsocialist countries and their welfare states. Some of the new member states (Czech Republic, Hungary, Slovenia) have public expenditure levels and generosity of welfare states that in many respects approach (controlling for per capita income) the level of many old member states. Indeed, the lowest levels of inequality in the whole European Union are found in Nordic countries and then in the new members from Central Europe. On the other hand, in the Baltic countries or Romania, the situation is significantly different.

There has been a relative reluctance, both by researchers and policy-makers, to explore these differences, conceptualize them and examine their impact at the European and global level. ${ }^{2}$ There has also been only a limited theoretical debate on how to conclusively classify the new member states in terms of existing social models, modified/expanded versions of the existing ones or completely new ones. However, as discussed in detail in the next section, this debate is currently under way and has already produced some results.

In our view, these conceptual simplifications have been caused by a combination of three factors:

- Transition and Europeanization. The new member states have been in flux for the last two decades both as a part of the transition process and, particularly in late 1990s and early 2000s, as a part of the EU accession. With such dynamism, any conceptualization risks being outdated by the time it is finished;

\footnotetext{
${ }^{2}$ An illustrative prominent example straddling both the policy and the research community is a paper by Andre Sapir on "Globalization and the Reform of European Social Models", which was published both as a Bruegel Policy Brief in 2005 and in the Journal of Common Market Studies in 2006. In the (otherwise excellent and thought-provoking) paper, he uses (as an analytical shorthand) 4 social models of old member states based on a modified version of typology by Esping-Andersen (1990) and essentially ignores the new member states or any attempt at their conceptualization.
} 
- Apparent irrelevance of national political, economic and social context. Much of the social and economic change in the new member states has been driven by the inexorable forces of adjustment to market democracy, EU accession and globalization. In the face of such forces, the different domestic political, economic and social situation seems of minor importance;

- Dominance of country-based (or regionally-based) research. Much of the literature devoted to the topic has been country-based or looking at one of the sub-regions of the larger postsocialist arena (Central Europe, Baltics, Balkans);

However, this paper argues that while the process of social and economic change never stops, the welfare regimes in the new member states have assumed shapes, which have not changed in a significant manner during the recent years and are unlikely to do so in the short- to medium-term. Indeed, in an analogy to existing literature on welfare state retrenchment in OECD countries (Pierson (1994)), the situation in the new member states is notable for how resilient the basic architecture of the welfare states has been once it settled down after the initial years of transition, despite the dramatic nature of the political discourse. ${ }^{3}$

We will also argue against one homogenous model for all postsocialist welfare states. Domestic political, economic and social context is relevant for the shape of the welfare state. This claim, which would seem self-evident in the context of Western Europe, is also true for the new member states as shown by substantial differences in the shapes and internal logic of their welfare states. Originally clustered in several groups with different developmental paths, the postsocialist countries saw their welfare state policies homogenized into what Titmuss (1963) called "Leninist welfare state" even though the extent of the homogenization should not be overstated (see Szelewa (2007)). During 1990s, the welfare state regimes diverged during the transition despite similar external political and economic environment. (Aidukaite (1999, 2003 and 2006)

In other words, transition, Europeanization and globalization have not brought homogenization of the postsocialist welfare states, instead, significant divergences despite similar original starting points (Aidukaite (2003), Sirovatka and Saxonberg (2006)).

At the same time, the speed and extent of the overall welfare state change and retrenchment in all the new member states during the whole transition has few, if any parallels in experience of other countries (Vaughan-Whitehead (2003)). This is true even in countries with the smallest rupture with the pre-1989 shape of their welfare states (e.g. Czech Republic, Hungary, and Slovenia). Therefore, while there has been a significant level of stability in the new paradigm, once it has been established, the changes involved in the rupture with the "Leninist" model have been of an order of magnitude greater than anything experienced in Western Europe or North America during 1980s and 1990s.

\footnotetext{
${ }^{3}$ One exception where the political hype of change and policy reality match to some extent are the Slovak "reforms" of the 2002-2006 period, but even these reforms are an apex of a long-standing process and resulted only in a limited change in the shape of the welfare state.
} 
Many earlier studies, which included Eastern Europe, observed the welfare state development in this region as falling (following Esping-Andersen's or Titmuss' typologies) within the liberal or residual regime (see Ferge (1997, 2001); Standing (1996)), in which welfare is based on a mix of social insurance and social assistance, and a partial privatisation of social policy. However, it should be pointed out that some of those studies tend to over-generalise and treat welfare state developments as if they were homogeneous throughout Eastern Europe (Aidukaite (2004), Fodor et al. (2002)). Kangas (1999) has concluded that to place the post-socialist countries in the prevailing welfare state typologies is rather problematic. Other studies have also emphasised emerging differences among Eastern European countries (Manning (2004), Fodor et al. (2002)).

However, the recent attempts show that authors have been trying to group Eastern European countries into a distinct regime that does not fall into Esping-Andersen's trilogy (see e. g. Aidukaite (2004); Kaariainen and Lehtonen (2006); Oorschots and Arts (2005); Wehner et al. (2004)). This regime is called Eastern European or postsocialist and is characterized as having characteristics from both the liberal and conservative corporatist regimes as well as some distinct features of the post-socialist countries, such as high coverage, but relatively low benefit levels and low level of trust in state institutions. Nevertheless, the theoretical and empirical validity of the attempts to group these countries into distinct regime are rather weak, since these studies neither cover all countries, nor they are based on solid comparative data that prove the existence of the post-socialist (or Eastern European) welfare regime.

\section{Conceptual framework}

The paper argues that to understand the postsocialist wefare state, one needs to understand the forces that have shaped over the last two decades. To understand these force, we need to explore differences between individual countries and examine what they have in common and what is different.

However, the usual instruments used in analysing welfare regimes are less than useful in the case of postsocialist welfare states. This can be illustrated both for analysis of the shape of the welfare state and factors underpinning the welfare regime.

Let us start with the issue of how we define welfare state. For the EU-15 (and nonEuropean states), the literature generally rejects analysis based solely on the level of social expenditure, arguing that the underlying structure of the welfare state determines how the expenditure is distributed and what are its links to the social structure (e.g. Esping-Andersen (1990)). Therefore, the Esping-Andersen typology is based on the dimensions of de-commodification, social stratification and publicprivate mix rather than on the level expenditure as such.

However, this does not mean that the level of expenditure is irrelevant. Table 1 shows the level of expenditure on social protection by each EU-15 country colour-coded according to a modified Esping-Andersen typology with the Mediterranean group added. As we can see, the social-democratic model is associated with high level of expenditure on social protection, followed by the conservative model and then the Mediterranean model. This visual interpretation is supported by the fact that correlation between the size of the social protection expenditure among the EU-15 
countries and the welfare state type is relatively high at $0.65 .^{4}$ However, this also indicates there are other variables that need to be taken into account.

Table 1: Social protection expenditure as \% of GDP, 2005

\begin{tabular}{lr} 
Fweden & 32 \\
Denmark & 31.5 \\
Belgium & 30.1 \\
Germany & 29.7 \\
Austria & 29.4 \\
Netherlands & 28.8 \\
United Kingdom & 28.2 \\
\hline Finland & 26.8 \\
\hline Italy & 26.7 \\
Portugal & 26.4 \\
Greece & 24.7 \\
Luxembourg & 24.2 \\
Spain & 21.9 \\
Ireland & 20.8 \\
\hline Source: Eur & 18.2
\end{tabular}

Source: Eurostat

Therefore, the size of the welfare state clearly matters with regard to typology. At the same time, we would argue that some of the other criteria traditionally used to distinguish between different welfare regimes either cannot be applied in postsocialist countries or cannot be determined from the formal structure of the welfare states.

Social stratification of the transition countries has been in tumult and there is no welldeveloped conceptualization of the emerging class stratification that could be used for welfare regime analysis. Formal shapes of welfare systems are not very helpful for two reasons. First of all, most welfare states in Central and Eastern Europe are a mixture of other models in a way, which is rarely true in the EU-15 countries. More importantly, it can be quite misleading to look at the official structure of a particular subcomponent of a welfare system. For example, formally social insurance system can be in effect very close to residual and/or social-democratic depending on the level of benefits and "equalisation" between individuals of varying incomes. Therefore, decommodification can be better approximated by the level of expenditure than by the formal structure of the system

Looking at the social and political underpinnings of the welfare regime, the EspingAndersen typology and other political explanations of the differentiated shape of the EU-15 welfare state are also of limited direct utility. The transition has not been about construction of a welfare state, but about the reconstruction and downsizing of the Leninist welfare state.

For this reason, we propose to replace these other dimensions by analysis of the redistributive effects of the welfare state that would complement the data about the social protection expenditure. These are the effect of the social protection expenditure on the level of poverty and the relationship between this impact and the size of the social protection expenditure. At the same time, it is meaningful to look at the

\footnotetext{
${ }^{4}$ Liberal states are coded as 1 , Mediterranean as 2, conservative as 3 and social-democratic as 4 for the purposes of correlation analysis.
} 
emerging public-private mix, primarily in the area of pensions, where all countries but the Czech Republic and Slovenia have established compulsory private pension insurance of different sizes.

Therefore, we propose to look at the shape of postsocialist welfare states using the following variables that should together provide a map of sufficient plasticity:

- social protection expenditure

- effect of the social protection expenditure on the level of poverty

- the relationship between the two previous variables

- differences in public-private mix as measured by presence and size of the compulsory private pension pillar

The paper analyses which common factors can account for commonalities and differences with regard to these variables. We are going to investigate three candidates:

- $\quad$ size of the transition economic shock

- ethnic heterogeneity, particularly with regard to marginalised socially excluded groups

- poverty in the absence of social transfers

It would be optimal to analyse the relationship between these independent and dependent variables using regression analysis, however, given the small size of the sample (10 countries), the validity of results would be questionable. Therefore, we prefer to use correlation analysis even though correlation between various pairs of variables does not imply causality and also does not often allow to disentangle multivariate relationships. Nonetheless, if results are interpreted conservatively and combined with qualitative research, they can provide results superior to purely qualitative analysis.

In the analysis, we use the following dependent variables:

\section{Welfare state size - social protection expenditure as a \% of GDP and ratio between social protection expenditure and the overall public revenue in 2005}

The two sets of data measure the share of the social protection expenditure in the overall available financial resources in the country and all financial resources available to the government. One might ask why public revenue rather than expenditure is used for the second indicator. The reason is that public revenue is better for comparative purposes because it indicates resources that the public sector actually manages to extract from the economy. Public expenditure data, especially under the ESA95 methodology used in the EU, tends to be more volatile in new member states because they also frequently include non-cash one-time items (bank restructuring, PPP costs etc).

The data show range of $12.4 \%$ of GDP to $23.4 \%$ of GDP, a difference nearly equivalent to the one between the spending of the most and the least generous old member states (Sweden at 32\% and Ireland at less than 19\%). This indicates considerable variety between the new member states. 
Table 2: Social protection data, EU-10, 2005

\begin{tabular}{|l|r|r|}
\hline Country & Soc protection exp & soc prot/revenue \\
\hline Bulgaria & 16.1 & 39.7 \\
\hline Czech Republic & 19.1 & 46.3 \\
\hline Estonia & 12.5 & 34.5 \\
\hline Hungary & 21.9 & 51.3 \\
\hline Lithuania & 13.2 & 40.1 \\
\hline Latvia & 12.4 & 34.7 \\
\hline Poland & 19.6 & 50.3 \\
\hline Romania & 14.2 & 43.2 \\
\hline Slovenia & 23.4 & 53.1 \\
\hline Slovakia & 16.9 & 47.9 \\
\hline
\end{tabular}

Source: Eurostat

\section{Effect of social protection expenditure on inequality/poverty - absolute redistribution efforts}

The second group of variables includes those measuring the effect of social protection expenditure on inequality/poverty. Unfortunately, the only available data set that measures this effect across the EU-10 is the influence of transfer on the risk-ofpoverty. Therefore, we can only look at the effect of social protection expenditure on the inequality at the lower end of the income spectrum, not for the whole society. This measures the redistributive effects of social transfers.

Table 3 presents at the data in four columns. The first one shows risk-of-poverty after all social transfers. The other three columns show the effect of social transfers on the risk-of-poverty indicator - for all transfers and dividing them into pensions and other transfers.

The size of the transfer effect differs considerably from Hungary, where transfers decrease poverty by 33 percentage points, to Latvia, where they do so only by half of that (17 percentage points). The divergence is sharper for non-pension transfers, where the difference between the largest effect (14\% in Hungary) and the smallest one ( $3 \%$ in Bulgaria) is nearly $500 \%$, whereas for the pensions, the difference is only $100 \%$.

Table 3: Risk-of-poverty in EU-10 and influence of transfers, 2005

\begin{tabular}{|l|r|r|r|r|}
\hline & \multicolumn{3}{|l|}{ Decrease in risk-of-poverty due to } \\
\hline Country & $\begin{array}{l}\text { Risk-of- } \\
\text { poverty }\end{array}$ & pension & All transfers & $\begin{array}{l}\text { Non-pension } \\
\text { transfers }\end{array}$ \\
\hline Bulgaria & 14 & 24 & 27 & 3 \\
\hline $\begin{array}{l}\text { Czech } \\
\text { Republic }\end{array}$ & 10 & 17 & 29 & 12 \\
\hline Estonia & 18 & 13 & 20 & 7 \\
\hline Hungary & 16 & 19 & 33 & 14 \\
\hline Lithuania & 20 & 14 & 21 & 5 \\
\hline Latvia & 23 & 12 & 17 & 10 \\
\hline Poland & 19 & 20 & 30 & 12 \\
\hline Romania & 19 & 18 & 23 & 8 \\
\hline Slovenia & 12 & 17 & 29 & 27 \\
\hline Slovakia & 12 & 19 & & \\
\hline
\end{tabular}

Source: authors based on Eurostat data 


\section{Relationship between social protection expenditure and its effect on poverty - relative redistribution efforts}

As we already mentioned, the social protection expenditure in itself shows only one dimension of the welfare system and that is its overall generosity. However, there can be important differences in how the expenditure is distributed to social groups, which form an important part of the welfare regime typology. The second indicator then measured the redistributive

Therefore, we supplement the data on generosity and redistributive effort of the welfare system by a synthetic indicator comparing them. This indicator, shown in Table 4, does not have any intrinsic explanatory value in itself, but comparison of values across countries is meaningful in showing whether the redistributive effect is proportional to the size of the social protection expenditure.

For countries except Slovenia and Latvia, the ratio is between 1.5 and 1.7. The two countries have similar levels of poverty before transfers (40-41\% of the population), but while Slovenia has the highest social protection expenditure of all the 10 countries, Latvia has the lowest.

However, the Czech Republic, Hungary and Poland are clustered around the 1.51-1.53 range, while Estonia, Lithuania, Romania, and Slovakia cluster around 1.59-1.62. Bulgaria is an outlier at the upper end, with 1.68.

Table 4: Ratio of effect of social transfers on poverty to the size of social protection for EU-10 countries, 2005

\begin{tabular}{|l|r|}
\hline Country & Ratio \\
\hline Bulgaria & 1.68 \\
\hline Czech Republic & 1.52 \\
\hline Estonia & 1.6 \\
\hline Hungary & 1.51 \\
\hline Lithuania & 1.59 \\
\hline Latvia & 1.37 \\
\hline Poland & 1.53 \\
\hline Romania & 1.62 \\
\hline Slovenia & 1.24 \\
\hline Slovakia & 1.6 \\
\hline
\end{tabular}

Source: author, based on Eurostat data

In contrast the EU-15 countries have much lower though differing average scores. These show that the distance between the old and new member states is significant.

Table 5: Ratio of effect of social transfers on poverty to the size of social protection for EU-15 countries grouped according to the modified Esping-Andersen typology, 2005

\begin{tabular}{|l|r|}
\hline Welfare regime model & Average ratio \\
\hline Conservative & 1.02 \\
\hline Liberal & 1.03 \\
\hline
\end{tabular}


social democratic

Mediterranean

0.87

Source: author

\section{Public/private mix in the pension system}

The issue of the public/private mix is, of course, relevant for the whole social protection expenditure, however an extensive privatization has occurred in the EU-10 countries only in the area of pensions. Therefore, we use the indicator on the introduction and the size of the compulsory private pension pillars as a proxy for the public/private mix in welfare.

Table 6 shows the data. Except for the Czech Republic and Slovenia, all the countries have privatized parts of their pension system, but the extent differs from $5 \%$ in Bulgaria to $9 \%$ in Slovakia.

Table 6: Introduction and size of the compulsory private pension system

\begin{tabular}{|c|c|c|}
\hline Country & $\begin{array}{l}\text { Compulsory private pension pillar } \\
\text { introduction }\end{array}$ & Size of the contributions ( $\%$ of wages) \\
\hline Bulgaria & 2001 & $2 \%$ (increasing to $5 \%$ by 2005 ) \\
\hline $\begin{array}{c}\text { Czech } \\
\text { Republic }\end{array}$ & Not introduced & - \\
\hline Estonia & 2002 & $6 \%$ \\
\hline Latvia & 2001 & $2 \%$ (increasing to $10 \%$ by 2010 ) \\
\hline Lithuania & 2004 & $2.5 \%$ (increasing to $5.5 \%$ by 2007 ) \\
\hline Hungary & 1998 & $\begin{array}{l}6 \% \text { (originally intended to increase to } 8 \% \\
\text { in 2002) }\end{array}$ \\
\hline Poland & 1999 & $7.20 \%$ \\
\hline Romania & 2008 & $2 \%$ (increasing to $6 \%$ by 2016 ) \\
\hline Slovakia & 2005 & $9 \%$ \\
\hline Slovenia & Not introduced & - \\
\hline
\end{tabular}

Source: Beblavý and Žitňanský (2008) 
We now present the independent variables, which we believe can explain the differentiation in the dependent variables and thus the differentiation in welfare systems in the new member states.

\section{1. the size of the transition economic shock}

The first potential explanation development of the postsocialist welfare state is the size of the transition economic shock. The logic is as follows: unlike their Western counterparts, the governments of transition countries faced significant liquidity constraints during 1990s and the size of the shock to the country's economy was a key determinant in how severe the these constraints would be. Countries facing an unusually severe and sustained downturn of their economies had to, sooner or later, overhaul their fiscal policy to adjust to their means. Since social expenditure is one of the key elements of the public expenditure, it had to participate, to some degree in the adjustment. Due to path dependency effects, once the size of the welfare state was adjusted to these conditions, it did not change subsequently in a major way even if the economic conditions changed. Therefore, the size of the initial downturn is an important determinant of the overall shape of the welfare state up to this day.

Table 7 shows three possible ways of measuring the size of the shock. They are all based on comparing the developments in GDP with pretransition developments (year 1990). The first indicator measures what was the lowest point in economic output (which was reached in different years in different countries). The other two measure average values in the first five or ten years of transition. Together, they provide relatively robust indicators of the size of the transition economic shock.

As we can see, Poland faced the smallest shock, from which it recovered most quickly. Czech Republic, Hungary and Slovenia also did not see their economies drop dramatically, though they took somewhat longer to recover. Bulgaria, Romania and Slovakia faced more serious downturns with more lasting consequences though Slovakia managed to recover more quickly than the rest. And the three Baltic states faced dramatic drops in their economic production, from which they did not recover during the whole first transition decade.

Table 7: Size of the transition economic shock

\begin{tabular}{|l|r|r|r|}
\hline & \multicolumn{2}{|l|}{$\begin{array}{l}\text { average GDP } \\
\text { GDP trough }\end{array}$} & \multicolumn{2}{l|}{$\begin{array}{l}\text { average GDP } \\
\text { 91-00 }\end{array}$} \\
\hline Bulgaria & 0.76 & 0.87 & 0.84 \\
\hline Czech Republic & 0.88 & 0.9 & 0.94 \\
\hline Estonia & 0.69 & 0.75 & 0.79 \\
\hline Hungary & 0.85 & 0.87 & 0.93 \\
\hline Lithuania & 0.56 & 0.68 & 0.67 \\
\hline Latvia & 0.5 & 0.6 & 0.59 \\
\hline Poland & 0.93 & 1 & 1.16 \\
\hline Romania & 0.79 & 0.84 & 0.85 \\
\hline Slovenia & 0.86 & 0.91 & 1.01 \\
\hline Slovakia & 0.79 & 0.84 & 0.94 \\
\hline
\end{tabular}

Source: author, based on UN data

\section{Ethnic heterogeneity}


Ethnic heterogeneity has been used to explain differences between the generosity of welfare states, particularly between the US and Western Europe (Gilens (1999), Alesina and Edward Glaeser (2004) though others see a need for a more nuanced view (Soroka et al. (2004))

Since many of the new member states have large minorities, which differ from the majority population in terms of employment, poverty and exclusion, it is a topic worth investigating.

The structure and generosity of the welfare system can be related to the ethnic heterogeneity of the country due to the nature of solidarity in a society. If "others", particularly "undeserving" others are seen as benefitting disproportionately from the welfare state, this can weaken support for the social protection expenditure. Additionally, if the minorities are socially and politically marginalised, their ability to influence the shape of the welfare state can be limited.

To measure the ethnic heterogeneity, we divide the 10 countries into four countries depending on the level of ethnic heterogeneity as measures by the share of marginalised ethnic groups in the population, as shown in Table 8. Those, where there is no significant minority group associated with exclusion and poverty - Poland and Slovenia - get the lowest ranking. In the Czech Republic, Hungary Lithuania and Slovakia, the share of such groups is small, but relevant - up to $10 \%$ of the population. These are Roma except for Lithuania, where the relevant minority are Russians. In Bulgaria and Romania, the share of the minorities - Roma and (in Bulgaria) Turks - exceeds $10 \%$, but is less than 20\%. Finally, in Estonia and Latvia, the Russian minority represents a significant percentage of the population and exceeds $20 \%$.

Table 8: Ethnic heterogeneity in the EU-10 countries

\begin{tabular}{|l|l|l|}
\hline Level of ethnic heterogeneity & Country & The minority group \\
\hline None & Poland & - \\
\hline & Slovenia & - \\
\hline Low - up to $10 \%$ & Czech Republic & Roma \\
\hline & Hungary & Roma \\
\hline & Slovakia & Roma \\
\hline Medium $-10-20 \%$ & Lithuania & Russian \\
\hline & Bulgaria & Turks/Roma \\
\hline High - more than $20 \%$ & Romania & Roma \\
\hline & Estonia & Russian \\
\hline
\end{tabular}

Source: author based on Census data for non-Roma population and Rorke and Wilkens (2006) data for Roma

The classification excludes those minority groups, which are not subject to obvious marginalisation - Hungarians in Romania and Slovakia. However, even if these were included, the classification would change only marginally - Slovakia would move from low to medium heterogeneity and Romania would not move at all. 
It is worth noting that in the case of Roma, the estimates are not based on the official census data as these tend to underreport the Roma numbers, but are an average estimate of OSCE and human rights groups. (Rorke and Wilkens (2006))

\section{3. poverty/inequality before transfers}

The third potential factor investigated in the paper is the extent of poverty before transfers, which could conceivably drive the size and structure of the welfare state if these variables respond to social need rather than other factors. Data about the risk-ofpoverty before social transfers measures acuteness of inequalities at the lower end of the income spectrum. It is shown in Table 9.

Table 9: Risk-of-poverty before social transfers in EU-10, 2005

\begin{tabular}{|l|r|}
\hline Country & Risk-of-poverty rate before transfers \\
\hline Bulgaria & 41 \\
\hline Czech Republic & 39 \\
\hline Estonia & 38 \\
\hline Hungary & 49 \\
\hline Lithuania & 41 \\
\hline Latvia & 40 \\
\hline Poland & 49 \\
\hline Romania & 42 \\
\hline Slovenia & 41 \\
\hline Slovakia & 39 \\
\hline
\end{tabular}

Source: Eurostat

\section{Analysis of the data}

In the analysis we start by looking at the relationship between the independent variables and the social protection expenditure. Two of the three independent variables have very high correlation with the social protection expenditure in 2005:

The first is the size of the initial transition shock as measured by the drop in GDP per capita compared to 1990. The correlation between the size of the shock and the share of social protection in GDP ranges between 0.77 and 0.8 , and the correlation between the size of the shock and the share of social protection in the overall public revenue is between 0.79 and 0.83 . It is also important to note that the size of the initial shock is not associated with subsequent pre-transfer inequality (on the contrary, there is a weaker opposite correlation ranging from -0.46 to -0.51 between the two variables). Therefore, the relationship between the initial shock and the subsequent developments in social protection expenditure seem to be driven by economic limits rather than the social impact.

The second is the ethnic heterogeneity, particularly with regard to existence of distinct marginalised groups. The correlation between ethnic heterogeneity and the share of social protection in GDP is -0.8 , while the correlation between ethnic heterogeneity and the share of social protection among all public expenditure is -0.9 (even if all ethnic heterogeneity was taken into account, the correlations would still be -0.8 and $-0.83)$ 
Poverty levels before transfers are correlated with the level of social protection expenditure (0.51), but the correlations is weaker than for the preceding two factors.

Therefore, we can posit that a combination of these two factors - initial transition shock and ethnic heterogeneity) - is more strongly associated with the size of the social protection expenditure than the levels of pre-transfer poverty. These findings cannot be compared with the EU-15 countries as they have obviously not undergone the transition shock.

Now we progress to the analysis of the redistributive nature of the social protection expenditure.

We find that in the EU-10 countries the size of the social protection expenditure is strongly associated with redistributive effects of social transfers, particularly with regard to non-pension social transfers. The correlation between the size of the social protection expenditure and the decrease in poverty due to all transfers is 0.91 . When the correlation is disaggregated between pension and non-pension transfers, the correlation for pensions is 0.48 and for other transfers is 0.81 . In other words, size of the social protection expenditure is strongly associated with absolute redistributiveness of the system represented by effects of transfers on poverty. This general feature of the EU-10 countries is stronger than in the EU-15 states, particularly for non-pension transfers, where the correlation is 0.7 for all transfers, 0.31 for pensions and 0.41 for other transfers.

This picture is complemented by the ratio of the effect of social transfers on poverty to the size of social protection expenditure, which is a measure of relative redistribution of the welfare system. The ratio has no correlation with either the economic shock of transition or the poverty rate before transfers. However, it is weakly correlated with the ethnic heterogeneity (0.29). Therefore, we also find that while the economic shock of transition is strongly associated with the size of the welfare state and that has important implications for the absolute redistributive effects, it has no correlation with the relative measure of redistribution though there is a weak relationship with ethnic heterogeneity.

The ratio is also much higher than for the EU-15 countries, where the range for the EU-15 is 0.79 (Greece) to 1.22 (Germany) whereas the EU-10 countries, with the exception of Latvia and Slovenia, cluster between 1.5 and 1.7. Therefore, the much smaller welfare states of the EU-10 countries generally demonstrate more emphasis on redistribution to prevent poverty than the EU-15 countries. However, we find internal differentiation where the Czech Republic, Hungary and Poland have relatively larger and somewhat less redistributive welfare states than Estonia, Lithuania, Romania and Slovakia. The exceptions are Slovenia and Latvia. Slovenia reaches the lower end of the EU-15 social protection expenditure and also of the limited redistribution. On the other hand, Latvia presents an example otherwise unseen in the European Union - a very small welfare state that ignores redistribution.

Lastly, the private/public mix can be only partially explained by independent variables - only those countries with relatively small shocks and no or low ethnic heterogeneity (Czech Republic, Slovenia) have not established the compulsory private pension 
pillar. However, this does not explain why Poland and Hungary, two countries which fit both criteria have established relatively sizeable private pensions schemes.

\section{Conclusion - towards a welfare state typology for postsocialist welfare states}

In the absence of comparable data and history, we used slightly different instruments from those used in traditional analysis of welfare states to ascertain their shapes in the new member states from Central and Eastern Europe and to determine whether they show important differences compared to the old member states and what factors account for their developments.

Our conclusions can be grouped into two parts.

First of all, we conclude that the postsocialist welfare state is different from the welfare states of the old member states and does not resemble any of the four existing models as present in Europe. The welfare states of the EU-10 countries are much smaller than those in the western half of the continent and generally demonstrate much stronger emphasis on redistribution to prevent poverty.

In the second part, we focused on finding explanation for the size and the shape of the postsocialist welfare states and to make a stab at potential factors underlying a new typology for the new member states.

Our conclusion is that the size, and indirectly the shape, of the welfare state in the new member states is associated strongly with two factors:

- the size of the shock undergone by each economy during the transition

- ethnic heterogeneity, particularly with regard to clearly defined and marginalised minorities

We also find that the size of the social protection expenditure is strongly linked to its redistributive nature of the social transfers (what we call absolute redistributive dimension), but that the EU-10 countries are internally differentiated, with stronger relative redistribution effects for Baltics (except for Latvia), Bulgaria, Romania and Slovakia and weaker for the Czech Republic, Hungary, Poland, while Latvia and Slovenia present outliers with very weak relative redistribution effects of social protection.

We also find that the economic shock of transition has no correlation with the relative measure of redistribution or the risk-of-poverty before transfers though there is a weak relationship with ethnic heterogeneity.

Based on these findings, we suggest division of the Central and Eastern European welfare states into five groups shown in Table 10. The typology is based on the three dimensions of the welfare state identified above and position of each group along these dimensions is associated with potential determinants analysed in the paper. The term "potential determinants" is used because the established correlation does not prove causation.

Table 10: Five types of welfare regime in the new member welfare states 


\begin{tabular}{|l|l|l|l|l|l|l|}
\hline & \multicolumn{4}{|l|}{ Dimensions of the welfare state } & \multicolumn{2}{l|}{$\begin{array}{l}\text { Potential determinants of } \\
\text { welfare state size and } \\
\text { shape }\end{array}$} \\
\hline Type & Countries & $\begin{array}{l}\text { Size of } \\
\text { social } \\
\text { protection } \\
\text { exp }\end{array}$ & $\begin{array}{l}\text { Absolute } \\
\text { redistributive } \\
\text { effort }\end{array}$ & $\begin{array}{l}\text { Relative } \\
\text { redistributive } \\
\text { effort }\end{array}$ & Economic shock & $\begin{array}{l}\text { Ethnic } \\
\text { heter. }\end{array}$ \\
\hline Invisible & Latvia & L & L & L & H & H \\
\hline Liberal light & $\begin{array}{l}\text { Estonia, } \\
\text { Lithuania }\end{array}$ & L & L & H & H & H \\
\hline $\begin{array}{l}\text { Uncertain } \\
\text { middle }\end{array}$ & $\begin{array}{l}\text { Bulgaria, } \\
\text { Romania, } \\
\text { Slovakia }\end{array}$ & $\mathrm{M}$ & $\mathrm{M}$ & $\mathrm{H}$ & $\mathrm{M}$ & $\mathrm{L} / \mathrm{M}$ \\
\hline $\begin{array}{l}\text { Conservative } \\
\text { light }\end{array}$ & $\begin{array}{l}\text { Czech } \\
\text { Republic, } \\
\text { Hungary, } \\
\text { Poland }\end{array}$ & $\mathrm{H}$ & $\mathrm{H}$ & $\mathrm{M}$ & $\mathrm{L}$ & $0 / \mathrm{L}$ \\
\hline $\begin{array}{l}\text { Nearly } \\
\text { conservative }\end{array}$ & $\begin{array}{l}\text { Slovenia } \\
\text { Sourc: }\end{array}$ & $\mathrm{H}$ & $\mathrm{H}$ & $\mathrm{L}$ & $\mathrm{L}$ & 0 \\
\hline
\end{tabular}

Source: author

The "invisible" group contains Latvia and the term is used because Latvia provides a unique combination of a very small welfare state with much smaller redistributive efforts than its peers.

The "liberal light" group contains Estonia and Lithuania and the term is used because their residual welfare state is much smaller than those of European states usually classified in the residual model.

The "conservative light" group contains the Czech Republic, Hungary and Poland and the term is used because the combination of its features resembles the conservative model, but with much smaller size.

Slovenia is classified in a group of its own as "nearly conservative" because the size and shape of its welfare state puts it closer to some EU-15 countries (e.g. Germany, Austria) that to the other EU-10 countries.

Bulgaria, Romania and Slovakia are in the "uncertain middle" between the two categories and their classification is, to a certain degree, in the eyes of the beholder. Therefore, this typology should be seen as a provisional as it does not provide clear guide to the classification of these "middle" countries. 


\section{References}

Abrahamson, P. 1999. 'The Welfare Modelling Business', Social Policy \& Administration, 33, 4, 394-415.

Aidukaite, J. 1999. 'Baltic Welfare Model'. Revue Baltique. No 15

Aidukaite, J. 2003. 'From Universal System of Social Policy to Particularistic? The case of the Baltic States', Communist and Post-Communist Studies 36, 4, 405-426.

Aidukaite, J. 2006. 'Reforming Family Policy in the Baltic States - the Views of the Elites', Communist and Post-Communist Studies 39, 1, 1-23.

Alesina, A. and E. Glaeser 2004. Fighting Poverty in the US and Europe: A World of Difference. Oxford: Oxford University Press.

Arts, W. and J. Gelissen. 2002. 'Three worlds of welfare capitalism or more? A Stateof-the-Art report', Journal of European Social Policy, 12, 2, 137-158

Bambra, C. 2005. 'Worlds of Welfare and the Health Care Discrepancy', Social Policy and Society, 4, 31-41

Beblavý, M. and R. Žitňanský. 2008. Political consensus and sustainability of major social and economic reforms in postcommunist countries, unpublished manuscript

Castles, F. G. and D. Mitchell. 1992. 'Identifying Welfare State Regimes: the Links between Politics, Instruments and Outcomes', Governance, 5, 1-26.

Castles, F. G. and D. Mitchell. 1993. 'Worlds of Welfare and Famils of Nations', in F. G. Castes (ed.), Family of Nations: Patterns of Public Policy in Western Democracies. Dartmouth: Aldershot.

Crouch, C. 2001, 'Welfare state regimes and industrial relations systems: the questionable role of path dependency theory', in B. Ebbinghaus and P. Manow (eds.), Comparing Welfare Capitalism. Social Policy and Political Economy in Europe, Japan and the USA, Abingdon: Routledge

Esping Andersen, G. 1990. The three worlds of welfare capitalism, Princeton: Princeton University Press.

Ferge, Z. 1997. 'The Changed Welfare Paradigm: The Individualization of the Social', Social Policy and Administration, 31,1, 20-44.

Ferge, Z. 2001. 'Welfare and 'Ill-Fare' Systems in Central-Eastern Europe, in R. Sykes, B. Palier and P. M. Prior (eds.), consultant editor Jo Campling, Globalization and European Welfare States Challenges and Changes. Basingstoke: Palgrave, pp. 127-153. 
Fodor, E., Ch. Glass, J. Kawachi and L. Popescu. 2002. 'Family Policies and Gender in Hungary, Poland and Romania', Communist and Post-Communist Studies 35, pp. 475-490.

Gilens, M. (1999). Why Americans Hate Welfare: Race, Media and the Politics of Antipoverty Policy. Chicago: University of Chicago Press.

Hacker, J. S. 2004. 'Privatizing Risk without Privatizing the Welfare State: The Hidden Politics of Social Policy Retrenchment in the United States', American Political Science Review, 98, 243-260

Jenson, J. 1997. 'Who Cares? Gender And Welfare Regimes', Social Politics, 4,2, 182-187.

Kaariainen, J. and H. Lehtonen. 2006. The Variety of Social Capital in Welfare State Regimes - A Comparative Study of 21 Countries, European Societies 8 ,1, 27-57.

Kangas, O. 1999. Social Policy in Settled and Transitional Countries: a Comparison of Institutions and their Consequences (Ministry of Social Affairs and Health: 8 July 1999), Retrieved on 5 May 2003

Kasza, G. 2002. 'The Illusion of Welfare "Regimes"', Journal of Social Policy, 31, 271- 287.

Korpi, W. 2000. 'Faces of Inequality: Gender, Class, and Patterns of Inequalities in Different Types of Welfare State', Social Politics, 7, 2, 127-191.

Kwon, H. 1997. 'Beyond European Welfare Regimes: Comparative Perspectives on East Asian Welfare Systems', Journal of Social Policy, 26, 467-484.

Leitner, Sigrid, 2003: Varieties of Familialism. The Caring Function of the Family in Comparative Perspective, in: European Societies 5(4), 353-375.

Lewis, J. 1992. 'Gender and the Development of Welfare Regimes', Journal of European Social Policy, 2, 159-173.

Oorschots, W. v. and W. Arts. 2005. 'The Social Capital of European Welfare States: the Crowding out Hypothesis Revised', Journal of European Social Policy 15, 1, 5-26.

Pierson, P. 1994. Dismantling the Welfare State?: Reagan, Thatcher, and the Politics of Retrenchment. Cambridge: Cambridge University Press

Pierson, Ch. 1995. Beyond the Welfare State. Cambridge: Polity Press

Pierson, P. 2004. Politics in Time: History, Institutions, and Social Analysis. Princeton: Princeton University Press.

Rorke, B. and A. Wilkens. 2006. Roma Inclusion: Lessons Learned from OSI's Roma Programming. New York: OSI 
Sainsbury, D. (ed.). 1999. Gender and Welfare State Regimes, Oxford: Oxford University Press.

Sapir, A. 2006. 'Globalization and the Reform of European Social Models', JCMS: Journal of Common Market Studies, 44, 2, 369-390.

Sirovátka, T. and Saxonberg, S. 2006. 'Seeking Balance Between Work and Family After Communism', in Haas, L. and S. Wisensale, Families and Social Policy. New York : The Haworth Press, pp. 287-313 and Marriage and Family Review, 39, 3/4, 287-313.

Soroka, S., Johnston, R. and K. Banting (2004). "Ethnicity, Trust and the Welfare State," in Philippe Van Parijs, ed., Cultural Diversity versus Economic Solidarity. Brussels: Deboeck Université Press

Standing, G. 1996. 'Social Protection in Central and Eastern Europe: A Tale of Slipping Anchors and Torn Safety Nets', in Esping-Andersen, G. (ed.), Welfare States in Transition: National Adaptations in Global Economies, London: Sage Publications, pp. 225-256.

Szelewa, D. 2007. 'The Continuing Legacy of the Communist Legacy', Social Politics: International Studies in Gender, State \& Society, 14, 3.

Titmuss, R.M. 1963. Essays on the Welfare State. London: Allen and Unwin.

Vaughan- Whitehead, D.C. 2003. Eu Enlargement Versus Social Europe: The Uncertain Future of the European Social Model, Northhampton; Cheltenham: Edward Elgar Publishing.

Wehner C., P. Abrahamson, F. Murphy, R. Clark, A. Hahighasemi and S. O. Hort. 2004. 'The Role of the Different Actors in the Development of Social Policy', March 2004. Working paper. 